\title{
THE ROLE OF THE FOREIGN TRADE IN ENSURING FOOD SACURITY IN THE COUNTRIES OF THE WORLD: AN EMPIRICAL ANALYSIS
}

doi: $\quad 10.2478 /$ czoto-2019-0111

Date of submission of the article to the Editor: 02/12/2018

Date of acceptance of the article by the Editor: 25/01/2019

Natalia Baryshnikova ${ }^{1}$-orcid id: 0000-0002-6645-8212

Dorota Klimecka-Tatar ${ }^{2}$ - orcid id: 0000-0001-6212-6061

Olga Kiriliuk ${ }^{3}$ - orcid id: 0000-0001-7892-6987

${ }^{1}$ Saratov State Law Academy Russia

${ }^{2}$ Czestochowa University of Technology Poland, dorota.klimecka-tatar@wz.pcz.pl

${ }^{1}$ Omsk State Transport University Russia

\begin{abstract}
Trade in agricultural products is one of the most dynamically developing segments of the global market. The feature of the contemporary stage of world food trade development is that the leading exporters are also the largest food importers, combining the benefits of the international division of labor with the development of domestic agricultural production. In the paper, the role of foreign trade in ensuring food security has been evaluated by comparing the global index of food security and the share of imported food in the domestic market. As a result, the countries of the world have been divided into 4 groups. The first two groups include countries that ensure their citizens a high level of food security through imports, as well as or through their own efficient agricultural production. The third and fourth groups include countries which are not agrarian developed. The problems of hunger and malnutrition in these countries can potentially be solved with the help of foreign trade and increased efforts of the international community.
\end{abstract}

Keywords: Global Food Security Index, foreign trade, export, import, international trade

\section{INTRODUCTION}

The changing picture of the economy and politics is the key factor in the development of economic systems. International trade is a fundamental component of the new global economy, it affects almost all aspects of society (Delmer, 2005; Graczyk et al. 2018). In the context of global competition on the food market, one of the most important tasks of each country is the priority selection of the domestic foreign trade policy (Porkka et al., 2013; D'Odorico, et al., 2014). This depends on the food security of the country, the competitiveness of the agricultural sector on the domestic and foreign market, the standard of living and the degree of social goals. The main problem relates to the impact of the global economy on the possibility of access by 
the different countries citizen to the highest quality food products. It is also important to provide appropriate logistic channels (Dziuba and Ingaldi, 2017; Topolšek, et al., 2016). The main question to be answered is how should food security relate, on the one hand, and use the advantages of the international division of labor, on the other? What is the role of foreign trade in ensuring the economic and physical access of citizens to healthy food?

The aim of the study is to examine the impact of foreign trade on food security in countries around the world, taking into account their diversity in the level of agrarian potential and economic development. The research is based on the fact that both full food sovereignty and absolute dependence on food in the conditions of the contemporary system of global economic relations are not only impossible, but also inadequate. The scientific hypothesis assumes that the "agrarian" status does not guarantee the country's achievement of food security.

\section{METHODOLOGY AND RESEARCH}

Numerous scientific works (Baierab et al., 2014; Bhagwati and Srinivasan, 1983; Feenstra; 2016; Jovanović, 2015; Krugman, 1995; MacDonald et al., 2015; Porter, 1998; Strielkowski et al., 2017) are devoted to the analysis of the problems of international economic integration, foreign trade and its impact on economic growth and state development. In this paper, particular attention to the study of contemporary (the second half of the XX-beginning of the XXI century) scientific concepts has been paid. The importance of factors forming competitive advantages, as well as new patterns of international trade has been emphasized. The main methodological approaches to the study are dialectical, involving the study of international economic integration in: the dynamic approaches - food sector as regularly changing scheme and systemic approaches - considering the global food market as a system in the global level.

Research methods include general scientific methods. The method of scientific abstraction, analysis and synthesis, grouping, as well as the special methods of economic research (economic and statistical). The statistics information are based on the results of global market analysis from international organizations: UN, WTO, UN FAO, UNCTAD and others.

\section{RESULTS AND DISCUSSION}

The focus of modern economic research on world trade processes and its impact on the economic growth of countries and the development of individual sectors of the economy in recent years has been clearly shifted from studying the impact of foreign trade on the uneven economic development of countries (Balassa, 1985; Prebisch, 1959;), competitive advantage factors (Porter, 1998) and patterns of formation of global value chains (Gereffi, 1999; Kaplinsky, 2001) to analyze the effects of globalization and identify the causes of the free trade "crisis". So, E. Reinert, author of "How rich countries got rich, and why poor countries stay poor", proves convincingly that the country's prosperity is not the openness of its economy in free trade, but a combination of government regulation, reasonable protectionism and strategic investments (Reinert, 2007).

The trade of agricultural products is one of the most steadily developing segments of the world market. The main factor of such development is the ever-growing demand for food, especially in developing and less developed countries. The assessment of 
the dynamics of foreign trade in food indicates its stable growth. For the period from 1995 to 2016 export-import flows increased almost 3 times (UNCTAD). In Table 1 the world's leading exporters and importers of food are presented. Also the dynamics changes of export and import of food in the global food market are reported. An analysis of the data in the table 1 indicate that the two leading exporters (the EU and the USA) are simultaneously the largest food importers, reasonably combining the use of the advantages of the international division of labor and the principle of developing domestic agricultural production.

Table 1

Top 5 food exporters and importers in the world (based on WTO, 2018)

\begin{tabular}{|c|c|c|c|c|c|c|c|c|c|}
\hline & \multirow{2}{*}{$\begin{array}{l}\text { Volume, } \\
\text { billion dollars. } \\
2016\end{array}$} & \multicolumn{4}{|c|}{ Share in global export/import, \% } & \multicolumn{4}{|c|}{ Annual growth rate, \% } \\
\hline & & 2000 & 2005 & 2010 & 2016 & $\begin{array}{l}2010- \\
2016\end{array}$ & 2014 & 2015 & 2016 \\
\hline \multicolumn{10}{|c|}{ EXPORT } \\
\hline $\mathrm{EU}(28)$ & 518 & 44.0 & 45.9 & 40.4 & 38.3 & 2 & 1 & -13 & 3 \\
\hline USA & 136 & 12.6 & 9.0 & 10.0 & 10.0 & 3 & 5 & -12 & 3 \\
\hline Brazil & 68 & 3.0 & 4.4 & 5.4 & 5.0 & 2 & -4 & -10 & -4 \\
\hline China & 66 & 3.1 & 3.6 & 3.9 & 4.9 & 7 & 6 & -1 & 5 \\
\hline Canada & 46 & 4.1 & 3.5 & 3.3 & 3.4 & 4 & 5 & -5 & -1 \\
\hline \multicolumn{10}{|c|}{ IMPORT } \\
\hline EU & 518 & 43.5 & 46.8 & 41.4 & 37.3 & 2 & 2 & -12 & 1 \\
\hline USA & 138 & 11.1 & 10.1 & 8.5 & 9.9 & 6 & 8 & 1 & 2 \\
\hline China & 100 & 2.0 & 3.0 & 5.2 & 7.2 & 9 & 7 & -2 & -3 \\
\hline Japan & 64 & 10.5 & 7.4 & 5.6 & 4.6 & 0 & -4 & -9 & 2 \\
\hline Canada & 34 & 2.6 & 2.4 & 2.4 & 2.4 & 3 & 4 & -4 & -1 \\
\hline
\end{tabular}

The food exporting countries listed in Table 1 cannot be unambiguously assigned to agrarian countries, since an agrarian country is a state in which agriculture is the basis of the national economy and its main sphere. In such countries, most of the GDP and national income is created precisely in agriculture, which determines the specialization of the state in the international division of labor.

Estimating the proportion of the population employed in agriculture suggests that developed, developing and less developed countries are characterized by a significant differentiation of this indicator. If among developed countries the share of people employed in agriculture is significant only in Serbia and Romania (19.4\% and $25.5 \%$, respectively), then in the group of developing countries the share of people employed in agriculture more than $25 \%$ is already 25 countries. Among them are India (44.3\%), China (27\%), Ecuador (25.9), Egypt (25.4) and others. Most of the agrarian countries are represented by underdeveloped countries, where the large number of population is engaged in agriculture. Burundi is in the first place in the world in terms of people employed in agriculture, where over $90 \%$ of the population works in the agricultural production branch - about $40 \%$ of GDP. However, Burundi's agriculture is unproductive: the value added per worker in the industry is only $\$ 132$ (132nd in the world). Low productivity is not a factor threatening economy for developed and developing countries. But underdeveloped countries face the fact that labor productivity in the agrarian sector dominant in their economy has a critical impact on the standard of living and the scale of hunger and malnutrition, food prices and food security. For many countries of the world, expanding participation in the global food trade is an integral element of the national foreign trade strategy. However, the motives for such participation may be different. Some need to sell surplus agricultural products (from exporters) on the foreign market but the others need to ensure food 
security of the state (from importers). Obviously, food-exporting countries rely on the categories of competitiveness and efficiency, the achievement of which will contribute not only to the accelerated development of the country's agricultural sector, but also to the growth of the national economy. Importing countries, by contrast, are focused on achieving food security, i.e. physical and economic access of the population to healthy food (Hys, 2018). From this point of view, an increase in the volume of imported food can solve the problem of eliminating food shortages and reducing prices for it in the country. But at the same time, with the growth of imports, the country's dependence on food supplying countries is increasing, which entails additional risks (for example, dilution of domestic food production) and adversely affects economic stability. Thus, creating the conditions under which the foreign trade will contribute rather than prevent the improvement of food security and nutrition, is a key objective for any country

In order to identify the relationship of food imports and the level of food security of states, the authors used the matrix method. Despite a certain degree of convention, it allows to visualize the typology of countries of the world. The proposed matrix has a dimension of $2 \times 2$. The $X$ axis shows the food security index, the boundary of the low and high values of which is 60 points, the $Y$ axis is the share of imports in the country's food resources, calculated by the authors as the ratio of the cost of food imports to its resources, including domestic production and imports

Table 2

Matrix of the relationship of food imports and food security of the world (based on FAO Statistical Pocketbook)

\begin{tabular}{|c|c|c|c|}
\hline & \multicolumn{2}{|c|}{ Global Food Security Index } \\
\hline & & Iow & high \\
\hline 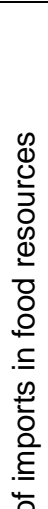 & 흥 & $\begin{array}{l}\text { Angola, Azerbaijan, Bangladesh, Bolivia, } \\
\text { Burkina Faso, Burundi, Cambodia, } \\
\text { Cameroon, Chad, Congo (Dem. } \\
\text { Rep.), Cote d'Ivoire, Dominican, Ecuador, } \\
\text { Egypt Ethiopia, Ghana, Guatemala, } \\
\text { Guinea, Honduras, India, Indonesia, } \\
\text { Kenya, Laos, Madagascar, Malawi, Mali, } \\
\text { Morocco, Mozambique, Myanmar, Nepal, } \\
\text { Nicaragua, Niger, Nigeria, Pakistan, } \\
\text { Paraguay, Peru, Philippines, Republic } \\
\text { Kazakhstan, Rwanda, Sierra Leone, Sri } \\
\text { Lanka, Sudan, Tajikistan, Tanzania, } \\
\text { Thailand, Togo, Uganda, Ukraine, } \\
\text { Venezuela, Vietnam Uzbekistan, Zambia }\end{array}$ & $\begin{array}{l}\text { Argentina, Australia, Brazil, Belarus, } \\
\text { Bulgaria, Canada, Chile China, } \\
\text { Colombia, Costa Rica, France, } \\
\text { Hungary, Malaysia, Mexico, New } \\
\text { Zealand, Poland, Romania, Russia, } \\
\text { Serbia, Spain, South Africa, South } \\
\text { Korea, Tunisia, Turkey, United States, } \\
\text { Uruguay }\end{array}$ \\
\hline 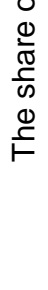 & 등 & $\begin{array}{l}\text { Algeria, Benin, El Salvador, Haiti, Jordan, } \\
\text { Senegal, Yemen }\end{array}$ & $\begin{array}{l}\text { Austria, Bahrain, Belgium, Czech } \\
\text { Republic, Denmark, Germany, Greece, } \\
\text { Finland, Ireland, Israel, Italy, Japan, } \\
\text { Kuwait, Netherlands, Norway, Oman, } \\
\text { Portugal, Panama, Qatar, Saudi Arabia, } \\
\text { Singapore Slovakia, Sweden, } \\
\text { Switzerland, United Arab Emirates, } \\
\text { United Kingdom }\end{array}$ \\
\hline
\end{tabular}

Depending on the ratio of food security level and the share of imported food, the countries of the world can be divided into 4 groups. The first group includes countries with a developed agricultural sector, which are the leading food producers in the world (e.g. Argentina, Brazil, Australia, USA) and have a high level of food security. They provide food not only to their people, but also actively export them, maintaining the food security of other countries. The countries of this group are largely differentiated 
by labor productivity in agriculture. A number of countries have highly developed, mechanized and automated agricultural production based on the latest achievements of agrarian science and modern technologies, which manifests itself in high efficiency and productivity indicators (USA, Canada, Australia, New Zealand). The countries of the middle level of development (Argentina, Brazil, China, Russia), on the contrary, increase the production of agricultural raw materials and food by extensive means. They have not yet reached the level of productivity of developed countries. However, in any case, the foreign trade of food and agricultural raw materials in the countries of the first group is significant, has a positive impact on economic growth and the development of agrarian production.

The second group consists of countries characterized by a high level of food security, and at the same time having a high share of imported food in the market (e.g. Austria, Great Britain, Norway, Japan, etc.). They either do not have a natural resource potential for agricultural production, or do not use it for production in the sufficient quantities for domestic consumption. Therefore they are net importers of food. Due to the high share of imports in all countries of this group there is a potential threat to their food and economic sovereignty. Nevertheless, the high level of development of these countries and sufficient resources for the purchase of imported food allow them to be in the top of the world ranking on the food safety index.

The third group consists of countries that do not produce food in the sufficient quantities to ensure food security. And at the same time do not have financial resources. They belong to the category of the poorest agrarian countries of the world, with highly specialized export-oriented agricultural production (cocoa, coffee, tea, cotton, bananas, sugarcane, etc.). By types of food, which should form the basis of a quality and affordable diet - there is an acute shortage in the underdeveloped countries. In this regard, the majority of less developed agrarian countries is characterized by widespread hunger and malnutrition among citizens, which also indicates a low level of food security. In Table 3 data of the hunger index in the underdeveloped agricultural countries in 2017 to 2010 have been compared.

Table 3

Hunger index in the underdeveloped agrarian countries of the world in 2010-2017 (based on Global Hunger Index, 2017)

\begin{tabular}{|l|c|c|l|c|c|}
\hline Country & \multicolumn{2}{|c|}{ Hunger index } & Country & \multicolumn{2}{c|}{ Hunger index } \\
\hline & $\mathbf{2 0 1 0}$ & $\mathbf{2 0 1 7}$ & & $\mathbf{2 0 1 0}$ & $\mathbf{2 0 1 7}$ \\
\hline Bangladesh & 37.6 & 26.5 & Mozambique & 48.7 & 30.5 \\
\hline Benin & 37.5 & 24.4 & Myanmar & 43.6 & 22.2 \\
\hline Burkina Faso & 47.9 & 27.6 & Niger & 52.6 & 34.5 \\
\hline Cambodia & 43.6 & 22.2 & Nigeria & 41.0 & 25.5 \\
\hline Cameroon & 39.6 & 22.1 & Rwanda & 56.3 & 31.4 \\
\hline Cote D Ivoire & 32.6 & 26.5 & Senegal & 37.3 & 18.4 \\
\hline Dem.Rep.Kongo & 36.0 & 25.6 & Sierra leone & 54.7 & 38.5 \\
\hline Ethiopia & 56.0 & 31.4 & Sudan & n.d. & 35.5 \\
\hline Ghana & 29.2 & 16.2 & Tadjikistan & 41.8 & 28.7 \\
\hline Guinea & 44.0 & 28.6 & Tanzania & 41.8 & 28.7 \\
\hline Honduras & 20.6 & 14.3 & Togo & 39.0 & 22.5 \\
\hline Kenya & 37.6 & 21.0 & Uganda & 39.2 & 32.0 \\
\hline Laos & 48.1 & 27.5 & Vietnam & 28.6 & 16.0 \\
\hline Madagascar & 43.6 & 38.3 & Yemen & 43.4 & 36.1 \\
\hline Malawi & 44.6 & 27.2 & Zambia & 52.3 & 38.2 \\
\hline Mali & 44.2 & 28.6 & Zimbabwe & 40.9 & 33.8 \\
\hline
\end{tabular}


The fourth group in table 2 includes 7 poor countries (Algeria, Benin, El Salvador, Haiti, Jordan, Senegal, Yemen), which, despite the relatively high share of imported products in the domestic food market, do not even provide an average level of food security. These countries also fall into the category of agrarian, however, the low level of labor productivity in agriculture and the lack of clear improvements in development do not make it possible to predict the strengthening of food security. Thus, it can be conclude that foreign trade will have a positive impact on the country's food security if the following criteria are met:

1. The country has solved the problem of hunger and malnutrition.

2. In the country with a resource potential for agricultural production, there is no critical dependence on food imports, i.e. the country is able to produce most of the food itself. The competitiveness of the country's agriculture allows not only to ensure its own food security, but also to carry out large-scale food exports, which have a positive impact on food security on a global scale.

3. In the country that does not have the resource potential of agricultural production, there are highly developed and highly efficient individual branches of agriculture for which natural conditions exist. The country has financial resources and the level of incomes of the population, sufficient to finance food imports, covering its shortage in the domestic market.

Most of the less developed agrarian countries have natural resources for agriculture and have a high proportion of the population engaged in agriculture. However, low labor productivity does not allow to produce enough food. If a country is export oriented, then it mainly sells low value added agricultural raw materials on the world market. The level of economic development and the incomes of the population cannot fill food shortages through import. As the result of which the hunger index in such countries is still very high. And thus, the research hypothesis is confirmed.

In this context, the opinion of the authoritative Swedish economist Erik Reinert seems very fair that a modern industrialized country can feed more people than an agrarian one. The fact that the state has natural advantages, such as, for example, fertile land resources and a favorable climate, does not mean its prosperity in the food sense. On the contrary, the intensive exploitation of natural factors of production, provoked by good resource security, with the aim of obtaining profit from exports entails a number of socio-economic problems and imbalances.

\section{CONCLUSIONS}

The current stage of world economic dynamics is characterized by increasing differentiation of the world countries according to all indicators of socio-economic development, including the level of food security. In conditions when international trade is a fundamental component of the new global economy, it affects almost all aspects of society. The role of foreign trade in ensuring the economic and physical accessibility of food is particularly high in developed countries. The less developed agrarian countries do not have efficient agricultural production and are not able to fully use the advantages of the international division of labor. As a result of which the indices of hunger and food security are beyond critical values. Considering the low probability of prospects for improving the situation in the main "poles" of hunger, the solution of the problem is seen in the further implementation of the measure system to combat hunger by the world community. 


\section{REFERENCES}

Baierab, S. L., Bergstrand, J.H., Feng, M., 2014. Economic integration agreements and the margins of international trade. Journal of International Economics 93 (2), 339-350. https://doi.org/10.1016/j.jinteco.2014.03.005

Balassa, B., 1985. Exports, policy choices, oil shock. Journal of Development Economics 18, 23-35.

Bhagwati, J.N. , Srinivasan, T.N. 1983. Lectures on international trade. Cambridge, Mass.: MIT Press.

D'Odorico, P., Carr, J. A., Laio F., Ridolfi L., Vandoni, S., 2014. Feeding humanity through global food trade. Earth's Future 2, 458-469. https://doi.org/10.1002/2014EF000250.

Delmer, D.P., 2005. Agriculture in the developing world: Connecting innovations in plant research to downstream applications. Proceedings of the National Academy of Sciences of the United States of America, 102(44), 157-160.

Dziuba, Sz.T., Ingaldi, M., 2017. Systems Providing Food Safety and its Perception by Polish Customers - Results of Survey. 17th International Multidisciplinary Scientific GeoConference (SGEM 2017), Albena, Bułgaria, STEF92 Technology Ltd. 843-850. https://doi.org/10.5593/sgem2017/53.

FAO Statistical Pocketbook, 2015. World Food and Agriculture,. Rome.

Feenstra, R.C., 2016. Advanced International Trade: Theory and Evidence. Second Edition, Princeton University Press, New Jersey USA.

Gereffi, G. A., 1999. Commodity Chains Framework for Analyzing Global Industries. Duke University. [electronic document] Access Mode: http://eco.ieu.edu.tr/wpcontent/Gereffi_Commodity Chains 99.pdf

Global Food Security Index. https://foodsecurityindex.eiu.com/

Graczyk, M., Kułyk, P., Kaźmierczak-Piwko, L., Augustowski, Ł., 2018. Ecological Innovations in Agricultural Production as a Pro-Development Factor of the Economy. MAPE 1(1), 603-612. https://doi.org/10.2478/mape-2018-0076.

Hys, K., 2018. Healthcare products and food supplements in Poland - a comparison. MATEC Web of Conferences 183.

https://doi.org/10.1051/matecconf/201818301006

Jovanović, M.N., 2015. The Economics of International Integration. Second Edition, Edward Elgar Publishing, Cheltenham UK, Northhampton USA.

Kaplinsky, R., Morris M., 2001. A handbook for Value Chain Research. The International Development Research Center.

http://www.prism.uct.ac.za/Papers/VchNov01.pdf

Krugman, P., 1995. Growing World Trade: Causes and Consequences. Washington, DC: Brookings Papers on Economic Activity.

MacDonald, G.K., Brauman, K.A., Sun, S., Carlson, K.M., Cassidy, E.S., Gerber, J.S., West, P.C., 2015. Rethinking Agricultural Trade Relationships in an Era of Globalization,BioScience. 65 (3), 275-289. https://doi.org/10.1093/biosci/biu225

Porkka, M., Kummu, M., Siebert, S., Varis, O., 2013. From food insufficiency towards trade dependency: A historical analysis ofglobal food availability. PLoS One 8(12). e82714. https://doi.org/10.1371/journal.pone.0082714

Porter, M. E., 1998. On Competition. Boston: Harvard Business School Press.

Prebisch, R., 1959. Commercial Policy in the Under-Developed Countries, American Economic Review 2, 251-252. 
Reinert, E., 2007. How rich countries got rich, and why poor countries stay poor. London, Constable.

Strielkowski, W., Tcukanova, O., Zarubina, Z., 2017. Globalization and economic integration: the role of modern management. Polish Journal of Management Studies 15(1), 255-261. https://doi.org/10.17512/pjms.2017.15.1.24

The Pocket Handbook of World Statistics, 2017. UN [electronic document] https://unstats.un.org/unsd/publications/pocketbook/files/RU-world-statspocketbook-2017.pdf

Topolšek, D., Jereb, B., Cvahte, T., 2016. Increasing competitiveness with intercompany integration of logistics and marketing functions. Production Engineering Archives 10(1), 29-32. https://doi.org/10.30657/pea.2016.10.08.

UNCTAD, 2017. Handbook of Statistics. United Nations. New York and Geneva. https://unctad.org/en/PublicationsLibrary/tdstat42_en.pdf

WTO, 2018. World Trade Stat review 2017. https://www.wto.org/english/res_e/statis_e/wts2017_e/wts2017_e.pdf 